\title{
Kinetic and thermodynamic characterization of the interactions between the components of human plasma kinin-forming system and isolated and purified cell wall proteins of Candida albicans*
}

\author{
Karolina Seweryn'1, Justyna Karkowska-Kuleta1 , Natalia Wolak1, Oliwia Bochenska1, \\ Sylwia Kedracka-Krok²,3, Andrzej Kozik 1, $\bowtie$ and Maria Rapala-Kozik1, $\bowtie$
}

1Department of Analytical Biochemistry, Faculty of Biochemistry, Biophysics and Biotechnology, Jagiellonian University in Krakow, Kraków, Poland; 2Department of Physical Biochemistry, Faculty of Biochemistry, Biophysics and Biotechnology, Jagiellonian University in Krakow, Kraków, Poland; ${ }^{3}$ Department of Structural Biology, Malopolska Centre of Biotechnology, Jagiellonian University in Krakow, Kraków, Poland

Cell wall proteins of Candida albicans, besides their best known role in the adhesion of this fungal pathogen to host's tissues, also bind some soluble proteins, present in body fluids and involved in maintaining the biochemical homeostasis of the human organism. In particular, three plasma factors - high-molecular-mass kininogen (HK), factor XII (FXII) and prekallikrein (PPK) - have been shown to adhere to candidal cells. These proteins are involved in the surface-contact-catalyzed production of bradykinin-related peptides (kinins) that contribute to inflammatory states associated with microbial infections. We recently identified several proteins, associated with the candidal cell walls, and probably involved in the binding of HK. In our present study, a list of potential FXII- and PPK-binding proteins was proposed, using an affinity selection (on agarose-coupled FXII or PPK) from a whole mixture of $\beta$-1,3-glucanase-extrated cell wall-associated proteins and the mass-spectrometry protein identification. Five of these fungal proteins, including agglutinin-like sequence protein 3 (Als3), triosephosphate isomerase 1 (Tpi1), enolase 1 (Eno1), phosphoglycerate mutase 1 (Gpm1) and glucose-6-phosphate isomerase 1 (Gpi1), were purified and characterized in terms of affinities to the human contact factors, using the surface plasmon resonance measurements. Except Gpm1 that bound only PPK, and Als3 that exhibited an affinity to HK and FXII, the other isolated proteins interacted with all three contact factors. The determined dissociation constants for the identified protein complexes were of $10^{-7} \mathrm{M}$ order, and the association rate constants were in a range of $10^{4}-10^{5} \mathrm{M}^{-1} \mathrm{~s}^{-1}$. The identified fungal pathogen-host protein interactions are potential targets for novel anticandidal therapeutic approaches.

Key words: Candida albicans cell wall, candidiasis, contact system, surface plasmon resonance

Received: 30 July, 2015; revised: 21 September, 2015; accepted 04 October, 2015; available on-line: 04 Decemer, 2015

\section{INTRODUCTION}

The cells of Candida albicans yeast - one of the most common fungal pathogens in humans (Karkowska-Kuleta et al., 2009) - are surrounded and protected by rigid capsules that are composed of branched polymers of glucose residues, containing $\beta-1,3$ and $\beta-1,6$ glyco- sidic linkages ( $\beta$-glucans), unbranched polymers of $\mathrm{N}$ acetyl-D-glucosamine residues, containing $\beta-1,4$ linkages (chitin), glycoproteins anchored to the polysaccharide framework, and a small amount of lipids (Klis et al., 2009). The fungal cell wall is an active and dynamic interface for mutual interactions between the pathogen and the host (Free et al., 2013). Of all cell wall components, proteins are believed to play the most versatile and specific roles in the candidal pathogenicity (Chaffin et al., 2008; Heilmann et al., 2012). In particular, numerous cell wall-associated proteins, collectively called adhesins, bind to proteinaceous targets at the cell surfaces and in body fluids of the human host (de Groot et al., 2013). These adhesion phenomena are essential for the initial stages of the host colonization that rely on the adherence to epithelial barrier, as well as for further spreading of the infection due to the penetration of the extracellular matrix into deeper tissues, dissemination with the blood and adsorption to endothelial cells (Filler et al., 2006; Tronchin et al., 2008). Another, albeit much less recognized binding activity of the candidal cell wall proteins (including the major adhesins), is directed at proteins of the major, blood-derived systems of the biochemical homeostasis of the human host that require cascade-activated proteolysis, such as the complement (Luo et al., 2009), the fibrynolysis (Crowe et al., 2003) and the kinin-generating system (Rapala-Kozik et al., 2008). These interactions have been hypothesized to help the pathogen to evade the host immune system and to disseminate within the host organism.

e-mail: maria.rapala-kozik@uj.edu.pl (M. Rapala-Kozik),

andrzej.kozik@uj.edu.pl (A. Kozik)

*The results were presented at the 6th International Weigl Conference on Microbiology, Gdańsk, Poland (8-10 July, 2015).

Abbreviations: ACN, acetonitrile; Als, agglutinin-like sequence; BSA, bovine serum albumin; DTT, dithiothreitol; EDC, 1-ethyl-3-(3dimethylaminopropyl)carbodiimide; Eft2, elongation factor 2; Eno1, enolase 1; ESI, electrospray ionization; FXII, coagulation factor XII; Glk4, hexokinase 2; GIr1, glutathione reductase; Gnd1, 6-phosphogluconate dehydrogenase; Gpm1, phosphoglycerate mutase1; HK, high-molecular-mass kininogen; Hyr1, hyphally-regulated protein 1 ; MS, mass spectrometry; NHS, N-hydroxysuccinimide; PBS, phosphate buffered saline; Pgi1, glucose-6-phosphate isomerase; PPK, human plasma prekallikrein; Pra1, pH-regulated antigen 1; RU, resonance units; SA-HRP, horseradish peroxidase-conjugated streptavidin; SDS-PAGE, sodium dodecyl sulfate polyacrylamide gel electrophoresis; Sod3, superoxide dismutase 3; SPR, surface plasmon resonance; Tpi1, triosephosphate isomerase 1 
The plasma-derived kinin-generating system is also called "the contact system" because its activation depends on the adsorption of three proteins — highmolecular-mass kininogen (HK), coagulation factor XII (FXII) and plasma prekallikrein (PPK) - to negatively charged surfaces (Colman \& Schmaier, 1997). The kinins, proteolytically released from $\mathrm{HK}$ by active kallikrein, are vasoactive bradykinin-related peptides that regulate blood pressure and many other physiological processes but also function as potent proinflammatory mediators (CostaNeto et al., 2008). Therefore, the activation of the contact system can occur at the surfaces of both, the human cells, including endothelial cells (Joseph et al., 2001), neutrophils (Henderson et al., 1994) and macrophages (Barbasz \& Kozik, 2009), and the microbial pathogens, including bacteria (Frick et al., 2007; Oehmke \& Herwald, 2010) and Candida spp. yeasts (Rapala-Kozik et al., 2008; Karkowska-Kuleta et al., 2010).

A molecular characterization of interactions between the contact-system components and the proteins associated with the candidal cell wall is far from satisfactory. Recently, using an affinity chromatography on a kininogen-agarose gel, we identified several putative kininogen-binding factors at the surface of $C$. albicans hyphae (Karkowska-Kuleta et al., 2011). These included both typical adhesins from Als (agglutinin-like sequence) and Hyr (hyphally-regulated) protein families, and some atypical, cytoplasm-derived proteins — sometimes called the "moonlighting proteins" (Karkowska-Kuleta \& Kozik, 2014) — such as triosephosphate isomerase (Tpi), enolase (Eno) and phosphoglycerate mutase (Gpm). The first aim of our present study was to perform a similar qualification of candidal cell wall proteins in terms of the affinity to two other contact factors, PPK and FXII. The second aim was to prove the actual interactions between selected fungal surface proteins and the three contact-system components. For this purpose, several fungal proteins were isolated and purified, and their affinities to HK, FXII and PPK were quantitatively characterized with the use of surface plasmon resonance (SPR) measurements.

\section{MATERIALS AND METHODS}

Proteins. Human HK, FXII and PPK were purchased from Enzyme Research Laboratories (South Bend, IN, USA), bovine serum albumin (BSA) and $\beta-1,3$-glucanase from Sigma (St Louis, MO, USA) and horseradish peroxidase-conjugated streptavidin (SA-HRP) solution from MP Biomedicals (Solon, OH, USA).

Culturing C. albicans. C. albicans strain ATCC 10231 was cultured in YPD medium (1\% yeast extract, $2 \%$ soybean peptone and $2 \%$ glucose) for $16 \mathrm{~h}$ at $30^{\circ} \mathrm{C}$ with constant shaking. The hyphal forms were obtained by inoculating the stationary-phase cells into RPMI 1640 medium (PAA Laboratories GmbH, Pasching, Austria) and incubation for $72 \mathrm{~h}$ at $37^{\circ} \mathrm{C}$ with constant shaking.

Extraction of cell wall-associated proteins from C. albicans hyphae. In the present study, the mixtures of fungal cell wall-associated proteins were prepared from $C$. albicans hyphae either directly (i.e., without any pre-labeling) or after the hyphae had been first biotinylated with biotin N-hydroxysuccinimide ester (Casanova et al., 1992; Rapala-Kozik et al., 2008). These two types of protein extracts were obtained by treating the hyphae with $\beta$-1,3-glucanase and 2-mercaptoethanol, as described previously (Crowe et al., 2003; Rapala-Kozik et al., 2008). The SYTOX ${ }^{\circledR}$ Green (Invitrogen Life Tech- nologies, Carlsbad, CA, USA) and Trypan Blue (Sigma) staining was used to confirm that more than $98 \%$ cells remained viable after $\beta$-1,3-glucanase/2-mercaptoethanol treatment. After centrifuging the cells, the supernatant was dialyzed against phosphate-buffered saline (PBS) for 48 hours at $4^{\circ} \mathrm{C}$. The protein concentration was measured using the Bradford method (Bradford, 1976).

Affinity-chromatography isolation of the mixtures of FXII- and PPK-binding proteins from the whole extracts of $C$. albicans cell wall-associated proteins. FXII and PPK were covalently attached to Affi-Gel 10 (Bio-Rad, Hercules, CA, USA), using a procedure similar to that described previously (Karkowska-Kuleta et al., 2011). Briefly, $500 \mu \mathrm{g}$ of contact system proteins dissolved in $4 \mathrm{ml}$ of $100 \mathrm{mM}$ HEPES buffer $\mathrm{pH} 7.5$ (containing $80 \mathrm{mM} \mathrm{CaCl}_{2}$ in case of FXII solution) were incubated overnight at $4^{\circ} \mathrm{C}$ with $1 \mathrm{ml}$ of chromatographic gel previously washed with $20 \mathrm{ml}$ of cold, deionized water. After extensive washing, the free reactive groups on the gel were blocked with $0.1 \mathrm{M}$ ethanolamine, $\mathrm{pH}$ 8.0 for $2 \mathrm{~h}$ at $4^{\circ} \mathrm{C}$. These gels were used to adsorb the FXII- and PPK-binding proteins that, after washing out the unbound proteins, were eluted by boiling in $2 \%$ SDS (Karkowska-Kuleta et al., 2011). The protein mixtures obtained were analyzed by sodium dodecyl sulfate- polyacrylamide gel electrophoresis (SDS-PAGE) (Laemmli, 1970). The protein bands were excised, in-gel digested with trypsin and analyzed by mass spectrometry (Method A, see below) to identify the particular FXII- and PPKbinding proteins. For this analysis, only those bands were taken into account that did not appear in the SDSPAGE pattern of the samples obtained (i) from a control agarose gel prepared without immobilized FXII or PPK but in which the reactive groups were blocked with ethanolamine, and (ii) when the candidal protein sample was pre-mixed with a large excess of soluble FXII or PPK before application on the FXII- or PPK-coupled affinity gel, respectively (Karkowska-Kuleta et al., 2011).

Isolation and purification of contact factor-binding proteins - Als3, triosephosphate isomerase 1 and phosphoglucoisomerase $1-$ from $C$. albicans cell wall. The purification procedures involved: (i) high-performance ion-exchange chromatography on a Mono Q column (GE Healthcare/Pharmacia, Uppsala, Sweden); (ii) a qualification of the fractions for further processing on the basis of a detectable binding activity toward the contact factors that were immobilized in polystyrene microplates or on SPR chips; (iii) confirming, by SDS-PAGE and mass spectrometry, that the major proteins in the selected fractions are identical to some of putative HK-, FXII- and PPK-binding proteins, earlier identified by affinity chromatography (see above); (iv) high-performance gel filtration on a Superdex-200 column (Amersham Bioscience, UK); and (v) confirming the purity of proteins by SDS-PAGE and confirming their identity by mass spectrometry.

Ion-exchange chromatography. The whole protein mixture, extracted from $C$. albicans hyphae with $\beta-1,3-$ glucanase, was dialyzed against $20 \mathrm{mM}$ Tris buffer, $\mathrm{pH}$ 8.0, and filtered through a $0.45 \mu \mathrm{m}$ syringe filter. The clarified extract was applied to a Pharmacia Mono Q (Mono Q HR 5/5, $1 \mathrm{ml}$ ) chromatography column, preequilibrated with $20 \mathrm{mM}$ Tris, $\mathrm{pH} 8.0$, at a flow rate of 1 $\mathrm{ml} / \mathrm{min}$. The separations were performed using a Knauer (Berlin, Germany) chromatograph containing a HPLC Pump K-1001, a solvent organizer/proportioning valve $\mathrm{K}-1500$, an UV detector 2600 with a control unit IF2, and EuroChrom software for the pump control, data acquisition and analysis. The bound proteins were eluted 
from the column using a $60-\mathrm{ml}$ linear gradient of $0-1$ $\mathrm{M} \mathrm{NaCl}$ in $20 \mathrm{mM}$ Tris buffer, $\mathrm{pH} \mathrm{8.0.} \mathrm{The} \mathrm{fractions}$ $(1 \mathrm{ml})$ were collected, tested for binding to microplateor SPR chip-immobilized HK, FXII or PPK, and analyzed by SDS-PAGE and mass spectrometry (Method B, see below).

Analysis of binding of the $C$. albicans proteins to microplate-immobilized contact factors. HK ( $1 \mathrm{pmol} / 50 \mu \mathrm{l}$ per well) or PPK or FXII (3 pmol protein/50 $\mu$ l per well) were adsorbed onto MaxiSorp 96well microtiter plates by overnight incubation at $4^{\circ} \mathrm{C}$. After each step of the assay, the wells were washed with $150 \mu \mathrm{l} 1 \% \mathrm{BSA}$ in PBS. The wells were blocked for $1.5 \mathrm{~h}$ at $37^{\circ} \mathrm{C}$ with $3 \% \mathrm{BSA}$ in PBS. Mixtures of biotinylated cell wall proteins, at a final concentration of $15 \mu \mathrm{g} / \mathrm{ml}(25 \mu \mathrm{l})$, and the fractions after MonoQ chromatography, pre-dialyzed against PBS $(25 \mu \mathrm{l})$, were added to the washed wells and the microplates were incubated for $1.5 \mathrm{~h}$ at $37^{\circ} \mathrm{C}$. After washing, the wells were refilled with $50 \mu$ l solution of SA-HRP (1:4000 dilution in PBS) and incubated for $1 \mathrm{~h}$ at room temperature. Next, $50 \mu \mathrm{l}$ of 3,3',5,5'-tetramethylbenzidine (TMB, Sigma) were added into each well and after stopping the reaction with $2 \mathrm{M} \mathrm{HCl}$, the absorbance was measured at $450 \mathrm{~nm}$ in a Power Wave X Select microplate reader (Bio'Tek Instruments, Winoosky, VT, USA).

Qualitative SPR test for binding of fungal proteins to HK. HK was immobilized on CM5 chip of the BIACORE 3000 system (GE Healthcare, Sweden) in an immobilization buffer $(10 \mathrm{mM}$ sodium acetate, $\mathrm{pH}$ 5.0). The immobilization was performed at $25^{\circ} \mathrm{C}$ using 1-ethyl-3-(3-dimethylaminopropyl)carbodiimide (EDC), N-hydroxysuccinimide (NHS) and ethanolamine (Amine Coupling Kit, GE Healthcare) with a flow rate of $10 \mu \mathrm{l} /$ min for $7 \mathrm{~min}$. The level of immobilization reached 6000 resonance units (RU). Fractions after MonoQ column chromatography, pre-dialyzed against $10 \mathrm{mM}$ HEPES buffer with $100 \mathrm{mM} \mathrm{NaCl}, \mathrm{pH} 7.4$, were injected over immobilized $\mathrm{HK}$ and control flow cell of the chip at a flow rate of $30 \mu \mathrm{l} / \mathrm{min}$. The association and dissociation time was 120 seconds. The binding was analyzed in terms of RU at the SPR signal plateau. The chip surface was regenerated between binding cycles by injection of $2 \mathrm{M} \mathrm{NaCl}$.

Gel filtration. Selected fractions after the MonoQ chromatography were concentrated four-fold in Vivaspin 2 concentrators with a cut-off of $10 \mathrm{kDa}$ (Sartorius, Goettingen, Germany) and loaded on a Superdex 200 HR 10/30 (Amersham Bioscience, Sweden) column, equilibrated with $10 \mathrm{mM}$ HEPES, pH 7.4, containing $150 \mathrm{mM} \mathrm{NaCl}$. Proteins were eluted with the same buffer at a flow rate of $0.5 \mathrm{ml} / \mathrm{min}$. Fractions $(0.5 \mathrm{ml})$ were collected and analyzed by SDS-PAGE and mass spectrometry (Method B). The fractions, that contained electrophoretically-homogenous, desired proteins were pooled, dialyzed against $10 \mathrm{mM}$ HEPES, pH 7.4 and concentrated, if necessary. Protein concentration was determined by the Bradford method.

Purification of $\boldsymbol{C}$. albicans enolase 1. Enolase was purified by an already published method (Ballantyne \& Warmington, 2000). C. albicans was grown in liquid YPD medium at $30^{\circ} \mathrm{C}$ to the exponential phase. The cells were pelleted in a centrifuge, transferred to an Eppendorf tube and washed twice with PBS at room temperature to remove the culture medium. The cells were broken up in $500 \mu \mathrm{l}$ of cold water with protease inhibitors (Complete Tablets EDTA-free, EASYpack, Roche, Penzberg, Germany) by vigorous shaking with $0.45-\mathrm{mm}$ glass beads in a FastPrep FP120 Instrument cell breaker (level of 6.0 for 45 s) (Thermo Savant, Carlsbad, USA). Soluble extracts were separated from glass beads and cell debris by centrifugation $\left(2000 \times \mathrm{g}, 4^{\circ} \mathrm{C}, 2 \mathrm{~min}\right)$ and further clarified at $13000 \times \mathrm{g}$ at $4^{\circ} \mathrm{C}$ for $20 \mathrm{~min}$. Solid ammonium sulfate was added to the crude extract to $65 \%$ saturation. After centrifugation at $13000 \times g$ at $4^{\circ} \mathrm{C}$ for $20 \mathrm{~min}$, the supernatant was made $100 \%$-saturated with ammonium sulfate and centrifuged at $13000 \times \mathrm{g}$ at $4^{\circ} \mathrm{C}$ for $20 \mathrm{~min}$. The supernatant was discarded and the pellet was dissolved in $10 \mathrm{mM}$ Tris- $\mathrm{HCl}$ buffer, $\mathrm{pH}$ 9.0, containing $5 \mathrm{mM} \mathrm{MgSO}$, $1 \mathrm{mM}$ EDTA, $1 \mathrm{mM}$ 2-mercaptoethanol, dialyzed overnight against the same buffer, and applied to a Mono Q column (Pharmacia). The proteins were eluted using a $60 \mathrm{ml}$ linear gradient of $0-0.5 \mathrm{M} \mathrm{NaCl}$ at a flow rate of $1 \mathrm{ml} / \mathrm{min}$. Fractions with enolase activity (see below) were collected and dialyzed overnight against $15 \mathrm{mM} \mathrm{NaH} \mathrm{PO}_{4} / \mathrm{Na}_{2}-\mathrm{HPO}_{4}$ buffer, $\mathrm{pH}$ 6.2, containing $3 \mathrm{mM} \mathrm{MgSO}_{4}$. The dialysate was applied to a MonoS column (GE Healthcare) equilibrated with $15 \mathrm{mM}$ $\mathrm{NaH}_{2} \mathrm{PO}_{4} / \mathrm{Na}_{2} \mathrm{HPO}_{4}$ buffer, pH 6.2, containing $3 \mathrm{mM}$ $\mathrm{MgSO}_{4}$. The protein was eluted using the same buffer, with the flow rate of $1 \mathrm{ml} / \mathrm{min}$.

The enolase activity was determined spectrophotometrically, by measuring the absorption of the reaction product (phosphoenolpyruvate) in the Power WaveX reader. The reaction mixture contained $0.05 \mathrm{M}$ imidazole buffer, $\mathrm{pH}$ 6.8, $0.4 \mathrm{M} \mathrm{KCl}, 1 \mathrm{mM}$ 2-phosphoglyceric acid and $3 \mathrm{mM} \mathrm{MgSO}_{4}$ in a final volume of $1 \mathrm{ml}$. The reaction was performed at $30^{\circ} \mathrm{C}$ by measuring the changes in the absorbance at $240 \mathrm{~nm}$, for 6 minutes after the addition of enzyme.

Heterologous expression, overproduction and purification of $C$. albicans phosphoglycerate mutase 1 . RNA isolation and quantitative PCR. Yeast cells were disrupted with glass beads (425-600 $\mu \mathrm{m}$, Sigma) and TRI Reagent (Sigma) using FastPrep FP120 Instrument (6.0 $\mathrm{m} / \mathrm{s}$ for $45 \mathrm{~s})$. Total RNA was isolated using GeneJet RNA Isolation Kit with DNase treatment and the quality of RNA was assessed by separation in an agarose gel under denaturing conditions. First strand cDNA was synthesized using $2 \mu \mathrm{g}$ of total RNA and dT18 primers with M-MLV Reverse Transcriptase, and subsequently diluted twofold with water. PCR amplification was performed with a MJ Mini Personal Thermal Cycler (BioRad, Hercules, CA, USA), in a final volume of $10 \mu$, with a pair of $C$. albicans GPM1 gene-specific primers (Genomed, Warsaw, Poland):

forward primer:

5' CACAGCCAGGATCCGAATTCGATGCCAAAGTTAGT'T'TAG T'TAGACACG 3',

reverse primer:

5' GGT'TTCT'T"TACCAGACTCGAGTTAT'TTCT'T'TTGACCTTGA GCAGCAAC 3'.

The reaction conditions were: $95^{\circ} \mathrm{C}$ for $2 \mathrm{~min}$, followed by 30 cycles of $95^{\circ} \mathrm{C}$ for $30 \mathrm{~s}, 52^{\circ} \mathrm{C}$ for $30 \mathrm{~s}$, $74^{\circ} \mathrm{C}$ for $3 \mathrm{~min}$ and $74^{\circ} \mathrm{C}$ for $10 \mathrm{~min}$. PCR products were electrophoretically verified with a $1.5 \%$ agarose gel.

DNA constructs for GPM1 expression. The constructs for GPM1 expression were prepared using InFusion HD Cloning Kit (Clontech Inc., Mountain View, CA, USA) that utilizes $\geq 15$ bp overhangs of DNA inserts and linearized vector for a selective fusion. Gene sequence of GPM1 was amplified by PCR, purified with Gel-Out Concentrator Kit and introduced into the EcoRI- and XhoI-digested pETDuet-1 expression vector (Novagen, EMD Milipore, Billerica, MA, USA), allowing for the C-terminal fusion with His6 tag. The recombinant DNA was used for bacterial transformation and positive transformants were selected for their ampicil- 
lin resistance. Plasmids were then isolated with Plasmid Mini Kit (A\&A Biotechnology, Gdynia, Poland) and after sequence verification (Genomed) they were used for transformation of chemically competent Escherichia coli BL21 strains.

Expression and purification of His6-tagged recombinant Gpm1. Individual ampicillin-resistant BL21 colonies were selected for inoculation into LB medium supplemented with $100 \mu \mathrm{g} / \mathrm{ml}$ ampicillin. Bacterial cultures were grown at $37^{\circ} \mathrm{C}$ until the mid-logarithmic phase, and the expression was induced with $1 \mathrm{mM}$ isopropyl- $\beta$-D-thiogalactopyranoside. The growth was maintained for $3 \mathrm{~h}$ at $30^{\circ} \mathrm{C}$, next the cells were harvested and lysed by sonication, and then the supernatant and pellet fractions were separated by centrifugation at $20000 \times g$ at $4^{\circ} \mathrm{C}$ for $30 \mathrm{~min}$. The supernatant was loaded onto Ni-NTA Sepharose High Performance affinity matrix, pre-equilibrated with buffer A $\left(50 \mathrm{mM} \mathrm{NaH} \mathrm{PO}_{4}\right.$, $\mathrm{pH}$ 8.0, $10 \mathrm{mM}$ imidazole, $300 \mathrm{mM} \mathrm{NaCl}, 20 \%$ glycerol). The column was then washed with buffer B (50 $\mathrm{mM} \mathrm{NaH} \mathrm{PO}_{4}, \mathrm{pH} 8.0,20 \mathrm{mM}$ imidazole, $1 \mathrm{M} \mathrm{NaCl}$, $20 \%$ glycerol $)$ and buffer $\mathrm{C}\left(50 \mathrm{mM} \mathrm{NaH}_{2} \mathrm{PO}_{4}, \mathrm{pH} 8.0\right.$, $20 \mathrm{mM}$ imidazole, $300 \mathrm{mM} \mathrm{NaCl}, 20 \%$ glycerol) in order to remove the non-specifically bound contaminants. Recombinant His6-tagged Gpm1 was finally eluted with buffer D (50 mM NaH $\mathrm{PO}_{4}, \mathrm{pH} 8.0,250 \mathrm{mM}$ imidazole, $300 \mathrm{mM} \mathrm{NaCl}, 20 \%$ glycerol) and then subjected to ion exchange chromatography (Mono Q HR 5/5, $1 \mathrm{ml}$ ). The column was equilibrated with $50 \mathrm{mM} \mathrm{NaH} \mathrm{PO}_{4}$, $100 \mathrm{mM} \mathrm{NaCl}, \mathrm{pH} \mathrm{8.0,} \mathrm{and} \mathrm{protein} \mathrm{extracts} \mathrm{were} \mathrm{loaded}$ at a flow rate of $0.5 \mathrm{ml} / \mathrm{min}$. Bound proteins were eluted using a $25 \mathrm{ml}$ linear gradient of $0-1 \mathrm{M} \mathrm{NaCl}$ in $50 \mathrm{mM}$ $\mathrm{NaH}_{2} \mathrm{PO}_{4}$ buffer, $\mathrm{pH}$ 8.0, and the purity of selected fractions was verified by SDS-PAGE. Gpm1 samples were then dialyzed for $48 \mathrm{~h}$ against $10 \mathrm{mM}$ HEPES, pH 7.4.

Protein identification with mass spectrometry. Method A (for the identification of FXII- or PPKbinding proteins, affinity-isolated from the candidal cell wall). The previously described protocols (Karkowska-Kuleta et al., 2011) were applied, with some modifications. The protein bands (visualized with Coomassie Brilliant Blue staining of the SDS-PAGE gel) were excised, and the reduction with $50 \mathrm{mM}$ DT'T was carried out at $56^{\circ} \mathrm{C}$ for 45 minutes, followed by the alkylation with $55 \mathrm{mM}$ iodoacetamide at room temperature for 2 hours. After washing and dehydrating the gel, the proteins were digested in $15 \mu \mathrm{l}$ trypsin (Biocentrum, Krakow, Poland) solution $(10 \mathrm{ng} / \mu \mathrm{l}$ in $25 \mathrm{mM}$ $\mathrm{NH}_{4} \mathrm{HCO}_{3}, \mathrm{pH} 8.0$ ) at $37^{\circ} \mathrm{C}$ overnight. The peptide extracts were evaporated until dry and resuspended in $2 \%$ acetonitrile (ACN) with $0.05 \%$ trifluoroacetic acid (TFA). The nano-liquid-chromatography-coupled tandem mass spectrometry (nanoLC-MS/MS) was carried out as described previously, using an UltiMate 3000RS LC nano System (Dionex, Carlsbad, CA) with an Acclaim PepMap $75 \mu \mathrm{m} 100 \AA ̊$ Nano Series TM Column, and a coupled MicrOTOF-QII mass spectrometer (Bruker, Bremen, Germany) with an Apollo Source ESI nano-sprayer equipped with low-flow nebulizer. MS was operated in the standard data-dependent acquisition MS/MS mode, with a fragmentation of the most intensive precursor ions. The MS spectra were analyzed by searching against the Swiss Prot and NCBI protein databases, using an in-house Mascot server (v.3.0, Matrix Science, London, UK). The following search parameters were applied: taxonomic restriction - Fungi; enzyme specificity - trypsin; permitted number of missed cleavages - 1; fixed modification — carbamidomethylation $(\mathrm{C})$; variable modifications — oxida- tion $(\mathrm{M})$; protein mass - unrestricted; peptide mass tolerance $- \pm 20 \mathrm{ppm}$; fragment mass tolerance $\pm 0.05 \mathrm{Da}$.

Method B (for monitoring the fungal protein purification and the identification of final products). To identify the content of protein bands obtained after SDS-PAGE analysis of protein fractions, collected during the chromatographic purification, the gel bands were manually excised, destained at $37^{\circ} \mathrm{C}$ by sequential washing with water, $25 \mathrm{mM}$ ammonium bicarbonate $\left(\mathrm{NH}_{4} \mathrm{HCO}_{3}\right), 50 \% \mathrm{ACN}$ and $25 \% \mathrm{ACN}$, and after that subjected to the reduction with $10 \mathrm{mM}$ DTT in $25 \mathrm{mM} \mathrm{NH} \mathrm{HCO}_{3}$ at $60^{\circ} \mathrm{C}$ for $1 \mathrm{~h}$ and the alkylation with $55 \mathrm{mM}$ iodoacetamide in $25 \mathrm{mM} \mathrm{NH}_{4} \mathrm{HCO}_{3}$ for $45 \mathrm{~min}$ at room temperature in the dark. The excess reagents were washed out with $50 \% \mathrm{ACN}$. Then, the gel pieces were dehydrated in $100 \%$ ACN, dried in an Alpha 1-2 lyophilizer (Christ, Osterode, Germany) for 15 minutes, and dissolved in $15 \mu \mathrm{l}$ of trypsin (Promega, Madison, WI, USA) solution $\left(15 \mu \mathrm{l}, 0.1 \mu \mathrm{g} / \mu \mathrm{l}\right.$ in $\left.25 \mathrm{mM} \mathrm{NH} \mathrm{NCO}_{3}\right)$ and incubated on ice for 25 minutes. Afterwards, additional $20 \mu \mathrm{l}$ of $25 \mathrm{mM} \mathrm{NH}_{4} \mathrm{HCO}_{3}$ were added. The digestion was carried out at $37^{\circ} \mathrm{C}$ overnight. Peptides were extracted by sonication in $50 \% \mathrm{ACN}$ and $0.5 \%$ formic acid at $37^{\circ} \mathrm{C}$. Then, the obtained peptides were analyzed by LC-MS/MS using a DionexUltiMate 3000 UHPLC system (Dionex, Carlsbad, CA, USA) coupled with an HCT Ultra ETD II mass spectrometer (Bruker, Bremen, Germany). For this analysis, the peptides were separated on a $100 \mathrm{~mm}$ x $2.1 \mathrm{~mm}$ Accucore C18 column (particle size $2.6 \mu \mathrm{m}$ ) (Thermo Scientific, Carlsbad, CA, USA) at a flow rate of $0.2 \mathrm{ml} / \mathrm{min}$, using a $38 \mathrm{~min}$ gradient of $80 \%$ ACN with $0.1 \%$ formic acid $(1-45 \%)$. The mass spectrometer was operated in the standard MS/MS mode with simultaneous fragmentation of most intensive precursor ions by collision-induced dissociation and electron-transfer dissociation. The resulting lists of peaks were used to search against the SwissProt protein database with taxonomy restricted to Fungi, using an in-house Mascot server, and the following search parameters: enzyme specificity - trypsin, permitted number of missed cleavages - 1, fixed modification — carbamidomethylation (C), variable modifications - oxidation $(\mathrm{M})$, protein mass - unrestricted, peptide mass tolerance $- \pm 0.3 \mathrm{Da}$, and fragment mass tolerance $- \pm 1.3 \mathrm{Da}$.

Kinetic and thermodynamic characterization of candidal protein-contact factor interactions, using surface plasmon resonance (SPR) measurements. The experiments were performed using a BIACORE 3000 system (GE Healthcare) in a running buffer (10 $\mathrm{mM}$ HEPES, $150 \mathrm{mM} \mathrm{NaCl}$ and $0.005 \%$ (w/v) surfactant $\mathrm{P} 20, \mathrm{pH}$ 7.4). The purified fungal proteins were dialyzed against $10 \mathrm{mM}$ HEPES buffer to remove $\mathrm{NaCl}$ and immobilized onto a CM5 sensor chip (GE Healthcare), using a standard amine-coupling method. Flow cells were activated by injecting a mixture of 50 $\mathrm{mM}$ NHS:200 mM EDC. Subsequently, the purified fungal proteins - Als3, Tpi1, Gpi1 and Gpm1-in sodium acetate, $\mathrm{pH} 4.0$, and Eno1 in the same buffer, $\mathrm{pH} 4.5$, were injected for $7 \mathrm{~min}$. To block any remaining activated ester groups, ethanolamine was injected. Immobilizations were carried out at $25^{\circ} \mathrm{C}$. The immobilization level for Gpi1, Tpi1 and Eno1 was about 400 RU, for Gmp1 300 RU and for Als3 800 RU. Samples of HK, FXII or PPK at variable concentrations (in a range of 25-1200 $\mathrm{nM}$ ) were injected over the sensor chip at a flow rate of $30 \mu \mathrm{l} / \mathrm{min}$, at $25^{\circ} \mathrm{C}$. In 
the case of enolase-binding analysis, the samples and the running buffer contained $3 \mathrm{mM}$ magnesium ions. FXII and PPK samples contained protease inhibitors, $0.1 \mathrm{mM}$ phenylmethylsulfonyl fluoride (Sigma) and 1 $\mu \mathrm{M}$ aprotinin (Sigma), respectively. The association and dissociation were manifested as shifts in RU during the injection and after the change to the running buffer. Next, the surface was regenerated with $1 \mathrm{M} \mathrm{NaCl}$ at a flow rate of $30 \mu \mathrm{l} / \mathrm{min}$ for $30 \mathrm{~s}$. The binding parameters were obtained by the analysis of sensograms, using a BIAevaluation 4.1 software (GE Healthcare). Dissociation and association rate constants $\left(k_{\mathrm{d}}\right.$ and $\left.k_{\mathrm{a}}\right)$ were obtained with a simple Langmuir model (1:1) with drifting baseline and $K_{\mathrm{D}}$ values were calculated as the ratios of these values.

\section{RESULTS}

\section{Identification of putative FXII- and PPK-binding proteins in the whole extracts of $C$. albicans cell wall-associated proteins}

Agarose gels that contained covalently linked FXII and PPK allowed us to isolate two subsets of candidal cell wall-associated proteins that represented mixtures of putative FXII- and PPK-binding proteins. Particular candidate contact-factor binders were further identified by MS and are listed in Table 1. Surprisingly, only three true candidal adhesins - Als3, Als1 and Hyr1 - were found to possess an apparent contact-factor-binding activity. Als3 was found to interact with both FXII- and PPK-coupled agarose, but Hyr1 and Als1 were only adsorbed on agarose-immobilized PPK. Other identified FXII- and PPK binders represent a group that should be classified as "atypical", loosely bound cell wall con-
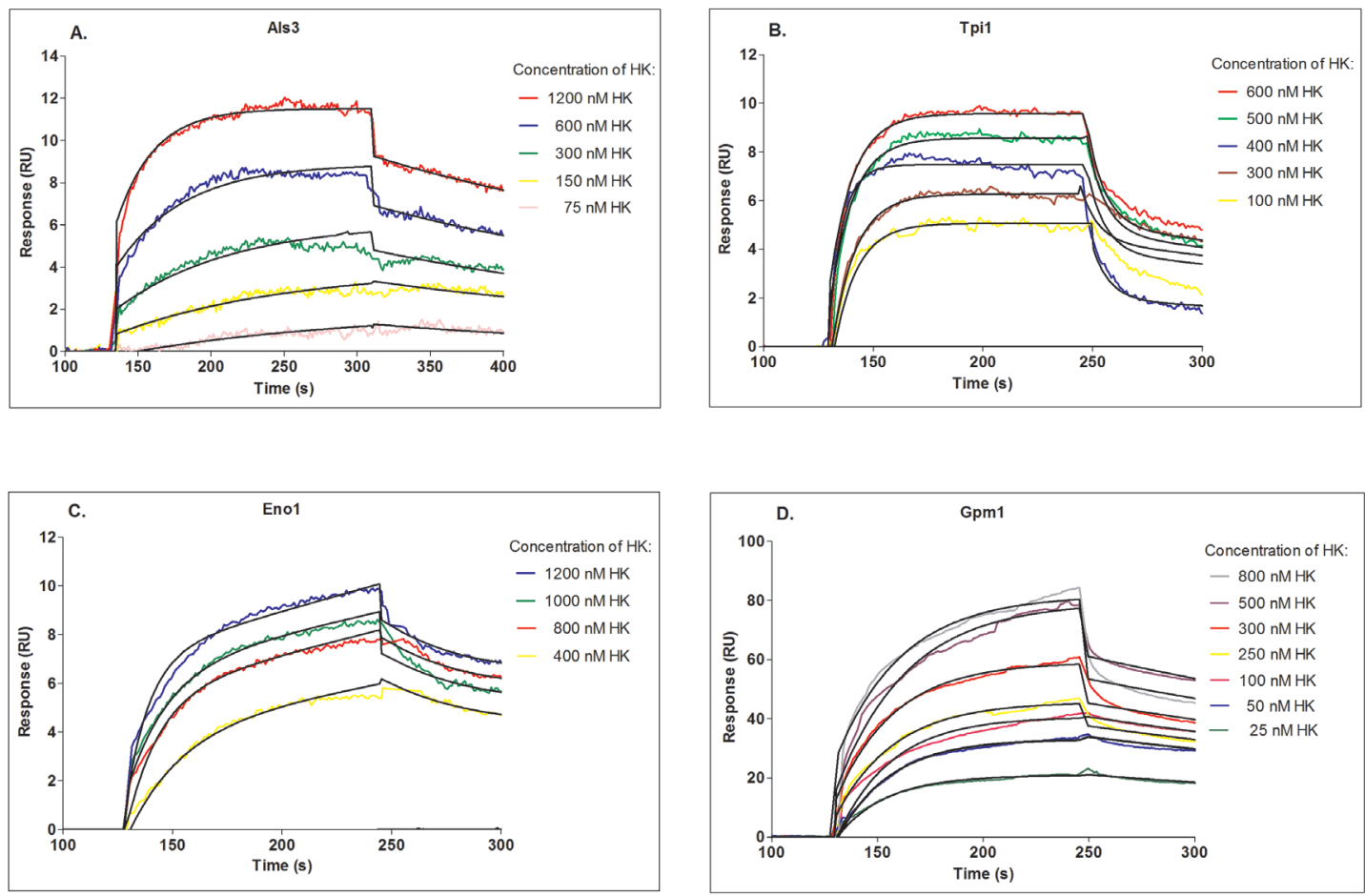

Figure 2. HK binding to immobilized Als3 (A), Tpi1 (B), Eno1 (C) and Gpm1 (D).

SPR analyses of the interactions between purified cell wall proteins Als3, Tpi1, Eno1, Gpm1 with HK. HK at various concentrations (25$1200 \mathrm{nM}$ ) was injected at a flow rate of $30 \mu \mathrm{l} / \mathrm{min}$, at $25^{\circ} \mathrm{C}$, over a CM5 chip with the immobilized protein. Global fits to the 1:1 binding model (with baseline drifting) are shown as solid black lines. 
Table 1. The mass spectrometry identification of FXII- or PPK-binding cell wall proteins from C. albicans.

Results from a representative analysis are shown. After SDS-PAGE of FXII or PPK affinity-selected proteins, the particular protein bands were excised and digested with trypsin. Analysis was conducted with an UltiMate 3000RS LCnanoSystem coupled with MicrOTOF-QII mass spectrometer equipped with Appollo Source ESI nano-sprayer. Data were evaluated by searching the SwissProt and NCBI protein databases through a Mascot server.

\begin{tabular}{|c|c|c|c|c|c|}
\hline Accession code & Protein name & $\begin{array}{l}\text { Molecular } \\
\text { mass (kDa) }\end{array}$ & Scores & $\begin{array}{l}\text { Number of } \\
\text { peptides }\end{array}$ & $\begin{array}{l}\text { Sequence } \\
\text { coverage (\%) }\end{array}$ \\
\hline & FXII-binding proteins & & & & \\
\hline gi|29373981 & Agglutinin-like sequence 3 (Als3) & 111.9 & 393.5 & 7 & 9.3 \\
\hline gi|68481380 & Elongation factor 2 (Eft2) & 91.9 & 240.1 & 4 & 7.0 \\
\hline gi|238880158 & Hexokinase 2 (Glk4) & 52.0 & 110.0 & 4 & 4.0 \\
\hline gi|238878982 & $\begin{array}{l}\text { Hypothetical protein } \mathrm{CaO} 19.2484 \text {, predicted aminopepti- } \\
\text { dase }\end{array}$ & 47.3 & 140.9 & 2 & 7.7 \\
\hline gi|68488457 & Enolase (Eno1) & 47.2 & 464.1 & 8 & 25.0 \\
\hline gi|68472093 & Triosephosphate isomerase (Tpi1) & 26.6 & 233.4 & 5 & 33.9 \\
\hline gi|68469783 & Phosphoglycerate mutase (Gpm1) & 27.4 & 393.5 & 6 & 37.9 \\
\hline gi|238883185 & Superoxide dismutase (Sod3) & 22.7 & 134.6 & 2 & 13.6 \\
\hline gi|238881595 & Proteasome component C5 & 27.1 & 272.2 & 6 & 33.1 \\
\hline gi|7271028 & 2-oxoglutarate dehydrogenase complex E2 component & 26.8 & 100.2 & 2 & 8.3 \\
\hline \multirow[t]{2}{*}{ gi|68475953 } & Hypothetical protein $\mathrm{CaO} 19.3226$, sterol transport protein & 21.2 & 148.0 & 3 & 18.2 \\
\hline & PPK-binding proteins & & & & \\
\hline gi|4105851 & Agglutinin-like cell surface protein (Als3) & 111.9 & 736.4 & 8 & 9.4 \\
\hline gi|1052565 & Hyphally regulated protein (Hyr1) & 93.6 & 611.7 & 9 & 9.2 \\
\hline gi|8927038 & Elongation factor 2 (Eft2) & 89.9 & 288.0 & 5 & 9.7 \\
\hline gi|68485129 & Glucose-6-phosphate isomerase (Pgi1) & 61.1 & 343.4 & 6 & 14 \\
\hline gi|68464879 & $\begin{array}{l}\text { Potential cyclopropane-fatty-acyl-phospholipid synthase } \\
\text { (Mts1) }\end{array}$ & 58.7 & 338.3 & 6 & 14.4 \\
\hline gi|723215216 & 6-phosphogluconate dehydrogenase (Gnd1) & 56.9 & 767.8 & 8 & 19.8 \\
\hline gi|238882555 & Glutathione reductase (GIr1) & 56.4 & 273.0 & 6 & 19.0 \\
\hline gi|238880158 & Hexokinase 2 (Glk4) & 52.0 & 155.0 & 3 & 8.5 \\
\hline gi|68488457 & Enolase (Eno1) & 47.2 & 454.1 & 6 & 22.7 \\
\hline gi|380719834 & Agglutinin-like protein, partial (Als1) & 35.2 & 166.2 & 2 & 10.4 \\
\hline gi|68471675 & $\begin{array}{l}\text { Hypothetical protein } \mathrm{CaO} 19.7949, \text { purine nucleoside pho- } \\
\text { sphorylase (Pnp1) }\end{array}$ & 33.4 & 289.2 & 5 & 23.5 \\
\hline gi|68470589 & $\begin{array}{l}\text { Hypothetical protein } \mathrm{CaO} 19.4230,20 \mathrm{~S} \text { proteasome subunit } \\
\text { (beta7) (Pre7) }\end{array}$ & 31.5 & 441.8 & 6 & 34.5 \\
\hline gi|68469783 & Phosphoglycerate mutase (Gpm1) & 27.4 & 526.7 & 7 & 37.9 \\
\hline gi|238879914 & Proteasome component (Pre6) & 27.4 & 399.0 & 7 & 38.8 \\
\hline gi|238881124 & Triosephosphate isomerase (Tpi1) & 26.6 & 338.2 & 5 & 27.1 \\
\hline gi|238880681 & Protein SNO4 & 25.8 & 174.8 & 3 & 19.9 \\
\hline gi|68475953 & Hypothetical protein $\mathrm{CaO} 19.3226$, sterol transport protein & 21.2 & 165.1 & 3 & 18.2 \\
\hline
\end{tabular}

three candidal cell wall proteins - Als3, Tpi1 and Pgi1 - in amounts sufficient for further SPR characterization. The yield (as well as the quality of final preparations) for two other proteins - Eno1 and Gpm1 - was not satisfactory, so that other procedures had to be applied. Eno1 was purified from the whole yeast lysate whereas Gpm1 was heterologously overproduced in E. coli. The SDS-PAGE characteristics of the protein preparations obtained (Fig. 1) showed their homogeneity, and the identity of each protein was confirmed by MS analysis (Method B), after the band excision and in-gel trypsin digestion (data not shown).
Kinetic and thermodynamic characterization of the interactions between three contact factors - HK, FXII and PPK - and purified C. albicans proteins - Als3, Tpi1, Pgi1, Eno1 and Gpm1 - using surface plasmon resonance measurements

All five purified candidal proteins were immobilized on the CM5 chips of BIACORE 3000 system to characterize their interactions with HK, FXII and PPK in terms of kinetic and thermodynamic constants. Goodquality sensograms (Figs. 2-4) were obtained for most of the contact factor-fungal protein pairs, thereby finally and directly confirming the interactions, previously only 

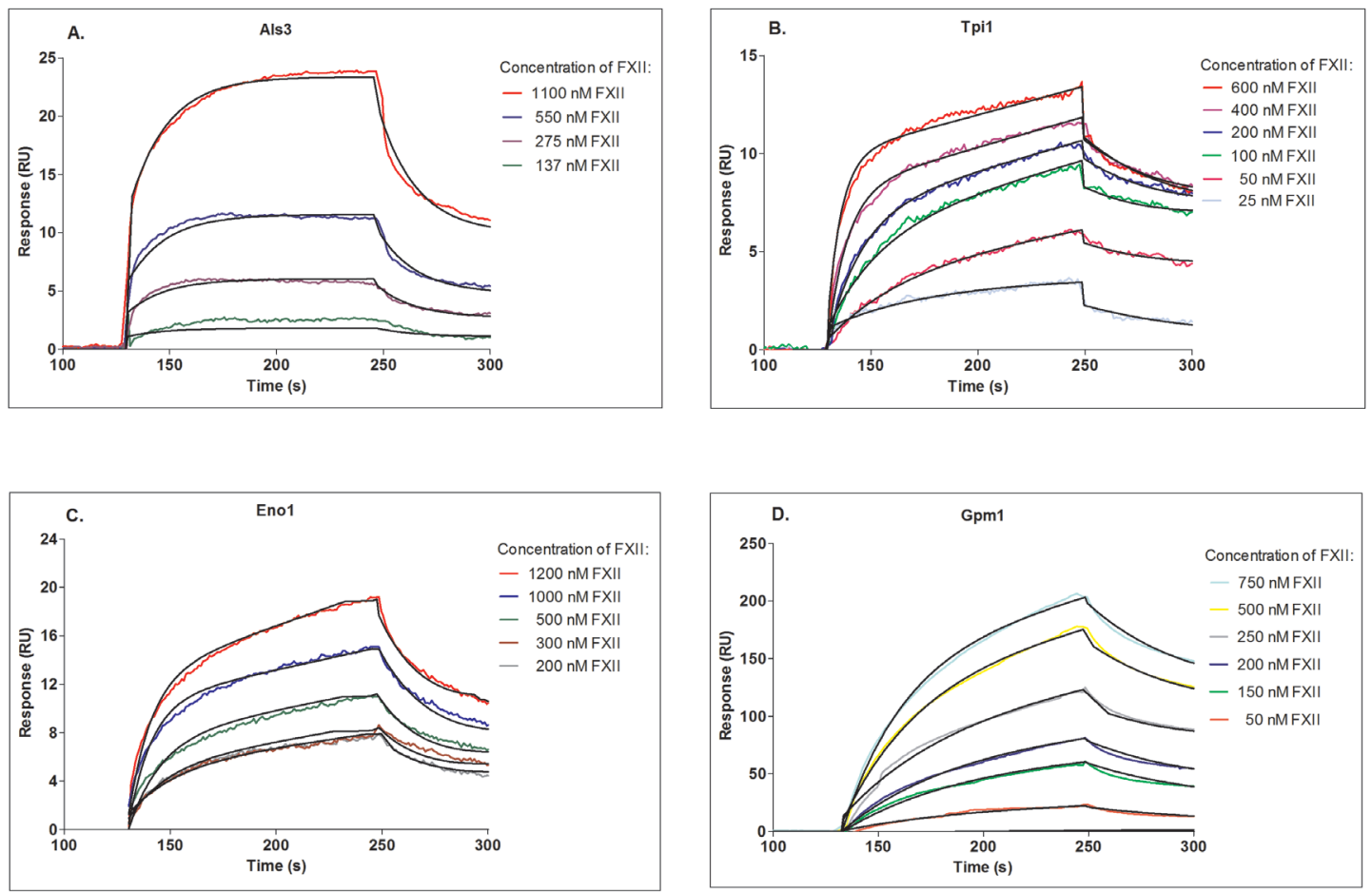

Figure 3. FXII binding to Als3 (A), Tpi1 (B), Eno1 (C) and Gpm1 (D).

SPR characteristics for the interactions between Als3, Tpi1, Eno1, Gpm1 with FXII. Global fits to the 1:1 binding model are shown as solid black lines. Sensograms for the binding of FXII to immobilized purified cell wall proteins of $C$. albicans were obtained after injections of the analyte (analyte concentrations range: 25-1200 nM) over a CM5 chip that contained the immobilized Als3, Tpi1, Eno1, Gpm1 at a flow rate of $30 \mu \mathrm{l} / \mathrm{min}$.
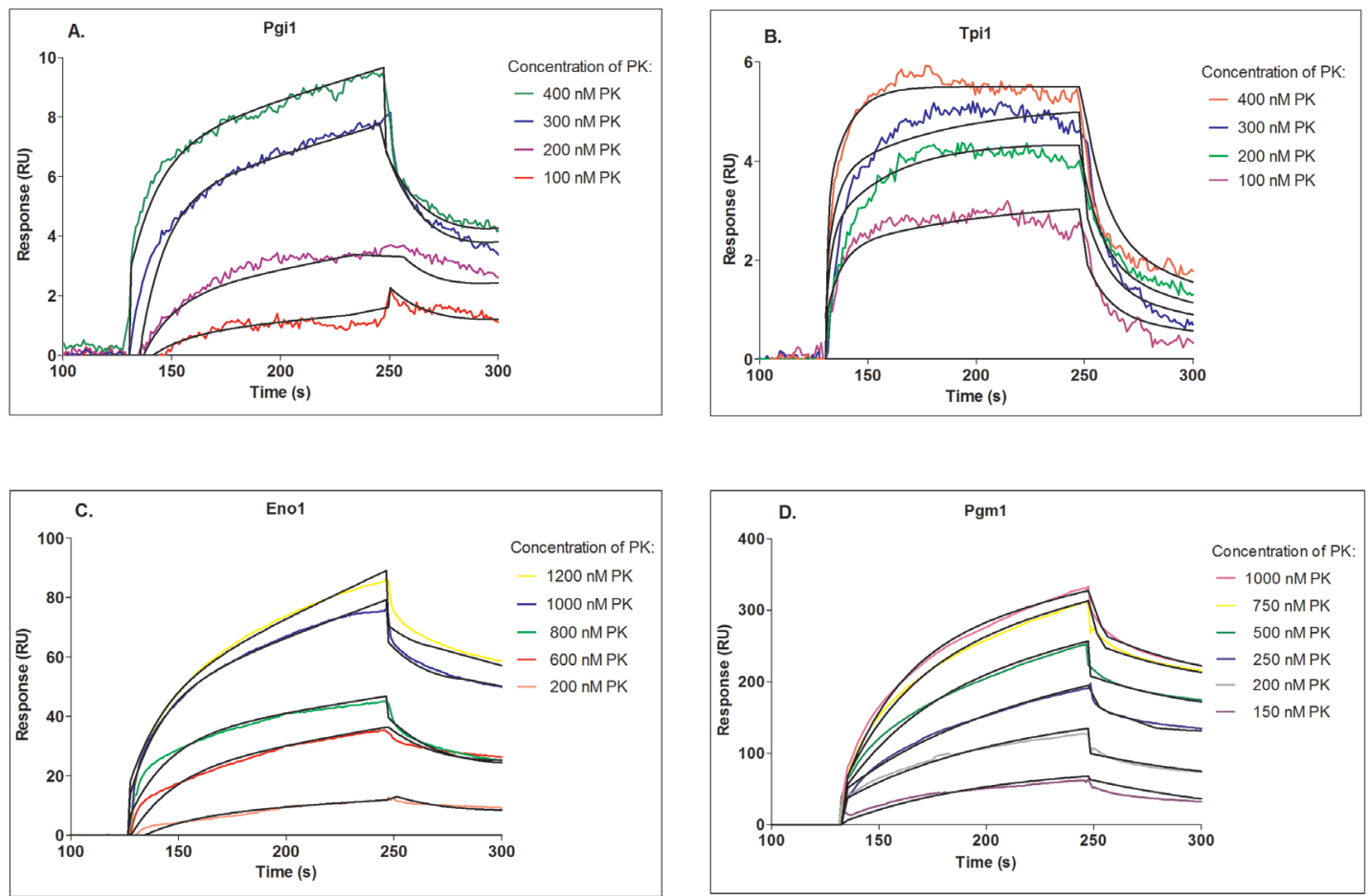

Figure 4. PPK binding to Pgi1 (A), Tpi1 (B), Eno1 (C) and Gpm1 (D).

SPR sensograms for the interactions of Pgi1, Tpi1, Eno1 and Gpm1 with PPK. The individual sensograms represent the responses to PPK solutions $(100-1200 \mathrm{nM})$ which were injected at a flow rate of $30 \mu \mathrm{l} / \mathrm{min}$ over the surface of CM5 chip that contained the immobilized proteins. The data were fitted with 1:1 binding model (shown as solid black lines). 
Table 2. Kinetic and thermodynamic parameters for the $C$. albicans cell wall protein-contact factor interactions.

The values were determined from the SPR measurements using Als3, Tpi1, Eno1, Gpm1 as the ligand and contact system proteins as the analyte.

\begin{tabular}{|c|c|c|c|}
\hline Protein & $k_{\mathrm{a}}\left(\mathrm{M}^{-1} \mathrm{~S}^{-1}\right)$ & $k_{\mathrm{d}}\left(\mathrm{s}^{-1}\right)$ & $K_{\mathrm{D}}(\mathrm{M})$ \\
\hline \multicolumn{4}{|c|}{ HK binding } \\
\hline Als3 & $4.33 \times 10^{4} \pm 1.16 \times 10^{3}$ & $9.22 \times 10^{-3} \pm 5.27 \times 10^{-4}$ & $2.13 \times 10^{-7} \pm 7.015 \times 10^{-11}$ \\
\hline Tpi1 & $3.86 \times 10^{5} \pm 1.10 \times 10^{4}$ & $3.04 \times 10^{-2} \pm 5.75 \times 10^{-4}$ & $7.87 \times 10^{-8} \pm 1.061 \times 10^{-10}$ \\
\hline Eno1 & $6.52 \times 10^{4} \pm 1.79 \times 10^{3}$ & $1.47 \times 10^{-2} \pm 7.63 \times 10^{-4}$ & $2.25 \times 10^{-7} \pm 7.708 \times 10^{-10}$ \\
\hline Gpm1 & $8.40 \times 10^{4} \pm 1.64 \times 10^{3}$ & $4.02 \times 10^{-2} \pm 5.31 \times 10^{-4}$ & $4.79 \times 10^{-7} \pm 4.935 \times 10^{-10}$ \\
\hline \multicolumn{4}{|c|}{ FXII binding } \\
\hline Als3 & $1.29 \times 10^{5} \pm 6.28 \times 10^{3}$ & $2.24 \times 10^{-2} \pm 2.06 \times 10^{-3}$ & $1.74 \times 10^{-7} \pm 1.102 \times 10^{-10}$ \\
\hline Tpi1 & $2.33 \times 10^{5} \pm 4.31 \times 10^{3}$ & $1.68 \times 10^{-2} \pm 5.28 \times 10^{-4}$ & $7.21 \times 10^{-8} \pm 7.117 \times 10^{-11}$ \\
\hline Eno1 & $4.88 \times 10^{4} \pm 1.31 \times 10^{3}$ & $3.56 \times 10^{-2} \pm 9.4 \times 10^{-4}$ & $7.33 \times 10^{-7} \pm 4.408 \times 10^{-9}$ \\
\hline Gpm1 & $2.68 \times 10^{4} \pm 3.77 \times 10^{2}$ & $1.47 \times 10^{-2} \pm 2.11 \times 10^{-4}$ & $5.48 \times 10^{-7} \pm 1.557 \times 10^{-9}$ \\
\hline \multicolumn{4}{|c|}{ PPK binding } \\
\hline Pgi1 & $7.44 \times 10^{4} \pm 4.75 \times 10^{3}$ & $4.54 \times 10^{-2} \pm 1.67 \times 10^{-3}$ & $6.09 \times 10^{-7} \pm 1.691 \times 10^{-9}$ \\
\hline Tpi1 & $6.31 \times 10^{4} \pm 4.4 \times 10^{3}$ & $4.22 \times 10^{-2} \pm 1.74 \times 10^{-3}$ & $6.69 \times 10^{-7} M \pm 3.720 \times 10^{-9}$ \\
\hline Eno1 & $1.57 \times 10^{4} \pm 5.82 \times 10^{2}$ & $3.16 \times 10^{-3} \pm 2.13 \times 10^{-4}$ & $2.13 \times 10^{-7} \mathrm{M} \pm 1.837 \times 10^{-9}$ \\
\hline Gpm1 & $2.66 \times 10^{4} \pm 3.81 \times 10^{2}$ & $1.05 \times 10^{-2} \pm 2.35 \times 10^{-4}$ & $3.97 \times 10^{-7} M \pm 9.815 \times 10^{-10}$ \\
\hline
\end{tabular}

hypothesized for HK (Karkowska-Kuleta et al., 2011) and, in this study, for FXII and PPK. A notable exception was that the interactions between Als3 and PPK, strongly suggested by the above affinity chromatography qualification, could not be confirmed by SPR measurements. On the other hand, as expected, Pgil presented the binding affinity to PPK only. Thus, four fungal proteins were analyzed for the binding activity toward each contact factor. A simple binding model (Langmuir model with a drifting baseline) could be fitted to the sensograms (as shown in Figs. 2-4), and the kinetic and thermodynamic parameters obtained together with the estimations of the fit quality (standard deviations) are presented in Table 2.

\section{DISCUSSION}

Among more than twenty species of the Candida genus that are pathogenic for humans, $C$. albicans is the most common, causing more than $70 \%$ cases of candidiases, ranging from relatively mild superficial mucosal infections to life-threatening fungaemia, deep-seated mycoses of almost all internal organs and systemic diseases (Mavor et al., 2005; Pfaller \& Diekema, 2007). Since $C$. albicans is also one of the major fungal pathogens in humans, the molecular aspects of its pathogenicity mechanism have been extensively studied in recent years. One process that plays an essential role for both, the initiation and further dissemination of candidal infections, is the direct physical contact (the adherence) of the yeast cell wall with the host tissues (Filler et al., 2006; Tronchin et al., 2008). This critical aspect of the fungal virulence largely depends on the interactions between the fungal cell wall-associated proteins and the proteins that are exposed on the surface of the host's cells or form the extracellular matrix (de Groot et al., 2013). Lesser known is the fact that candidal cell wall proteins can at- tract soluble proteins of the blood and other body fluids, some of them being involved in the maintaining the biochemical homeostasis of the human organism. A best characterized example of this type of $C$. albicans proteinhuman protein interaction is the binding of plasminogen that occurs via several candidal surface proteins such as pH-regulated antigen 1 (Pra1), Eno, Gpm, Eft, alcohol dehydrogenase, thioredoxin peroxidase, catalase, glyceraldehyde-3-phosphate dehydrogenase, phosphoglycerate kinase and fructose bisphosphate aldolase (Crowe et al., 2003; Jong et al., 2003; Poltermann et al., 2007; Luo et al., 2009). Notably, of these plasminogen binders only Pra1 belongs to typical cell wall proteins. Others are rather the "atypical", cytoplasm-originated proteins ("moonlighting" proteins) exposed on the candidal surface (KarkowskaKuleta \& Kozik, 2014).

Bradykinin-related peptides, collectively called kinins, are proinflammatory mediators, involved in almost any inflammation state and, therefore, playing important roles in numerous diseases (Blais et al., 2000; Colman \& Schmaier, 1997). Inflammation is a refined, complex response of the human organism to tissue damages or infections that aims at fighting the pathogenic factor and initiating the tissue repair (Karin et al., 2006). However, during the microbial infections, the surface-dependent activation of the kinin-forming system of the blood composed of HK, FXII and PPK - acts to some extent as a double-edged sword (Frick et al., 2007) because some of the kinin-exerted effects, such as the vascular permeability enhancement, can help the pathogen to disseminate within the host organism. Hence, numerous bacterial species have been shown to bind the contact factors through the surface-exposed proteins (Ben Nasr et al., 1995; Herwald et al., 1998; Oehmke \& Herwald, 2010; Rapala-Kozik et al., 2011).

The studies performed at our laboratory since 2008 have suggested that similar processes can also occur at the surface of fungal pathogens such as Candida spp. 
(Rapala-Kozik et al., 2008). One of the most important findings was that gathering all components of the contact system can cause the release of kinins from surfacebound $\mathrm{HK}$, and subsequently trigger inflammatory responses (Karkowska-Kuleta et al., 2010). Notably, three contact factors were shown to compete with each another for binding to candidal cells, suggesting that HK, FXII and PPK partly shared common receptors on the fungal surface (Karkowska-Kuleta et al., 2010). Only recently a proteomics-like approach has been applied to identify the HK-binding proteins, associated with C. albicans cell wall (Karkowska-Kuleta et al., 2011). In the present study we extended this approach to FXII and PPK interactions with candidal cell wall and confirmed that of about 10 previously suggested $\mathrm{HK}$ binders at least five - Als3, Eno1, Eft2, Tpi1 and Gpm1 — potentially bound all three contact factors and further two - Hyr1 and Gnd1 - presented a putative affinity to both, HK and PPK.

The identified fungal cell wall proteins, including both, the GPI-anchored true adhesins (Als1, Als3 and Hyr1) and the atypical cell wall-associated proteins (the "moonlighting" proteins), are well known to exhibit broad binding specificities, directed towards a range of host's proteinaceous targets. It should be kept in mind, however, that in the case of the contact system, the specificity of binding to the surface is not a critical prerequisite for the system activation. This system activates on various negatively-charged surfaces; all factors have to just gather together, the adsorption of FXII and HK induces conformation changes within their molecules that trigger FXII auto-activation, the active FXII initiates the cascade PPK/FXII mutual activation, and the active kallikrein releases kinins from the adsorbed HK (Colman \& Schmaier, 1997). Hence, the literature reports of the binding affinity of the putative HK-, FXII- and PPKbinding fungal proteins to other targets do not raise a doubt about the significance of the suggested fungal-human protein interactions but rather support the assignments that were deduced from our data.

The involvement of Als proteins in the contact factorbinding is consistent with the universal, major role of these proteins in the fungus-host adhesion (Sheppard et al., 2004). For example, the FXII- and PPK-binding Als3 protein and PPK-binding Als1 protein were reported to be responsible for adherence to collagen, fibronectin, laminin, endothelial and epithelial cells (Filler, 2006). Of the eight members of $C$. albicans Als family, Als3 makes the largest contribution in adhesion to human cells (Lin et al., 2014). It was shown that Als3 adhesin binds to $\mathrm{N}$-cadherin on endothelial cells, and E-cadherin on oral epithelial cells, through its N-terminal portion (Phan et al., 2007).

The other group of identified contact factor-binding candidal proteins includes glycolytic enzymes which have been found to act as "moonlighting" proteins (Karkowska-Kuleta \& Kozik, 2014). One of the best examined, abundant moonlighting protein is enolase. Enolase was proposed to play a role in bacterial, fungal and neurological diseases, fungal allergies, cancer and autoimmunity diseases (Pancholi, 2001). Moreover, it was reported that $C$. albicans enolase occurs on the cell surface (LópezVillar et al., 2006), is a major surface antigen (Sundstrom \& Aliaga, 1992) and is able to bind plasminogen (Crowe et al., 2003). Another fungal glycolytic enzyme, suggeted to interact with HK, FXII and PPK is Gpm1. It was reported to be also exposed on the fungal surface and bind the complement regulators and plasminogen (Poltermann et al., 2007). Less is known about the surface exposure and adhesive properties of Tpi1 (Pitarch et al., 2002) that is highly immunogenic and essential for fungal growth (Pitarch et al., 2001; Pitarch et al., 2004). The most enigmatic is Pgil that in our present study was found to bind exclusively to PPK. There is no data from other laboratories about its possible role on the candidal surface. The only relevant information concerns a bacterial species - Lactobacillus crispatus — in which Pgi is an extracellular protein that binds laminin and collagen I, favorably at acidic pH (Kainulainen et al., 2012).

Another cytoplasmic protein, Eft2, that in our studies was found to bind all three contact factors, was also reported to interact with plasminogen (Crowe et al., 2003), but still relatively little is known about the function of its surface-exposed form in candidal virulence. However, there are relevant literature reports concerning a bacterial analog of Eft2, elongation factor $\mathrm{Tu}$ (EF-Tu). EF-Tu can mediate the bacterial interaction with plasminogen, plasma factor $\mathrm{H}$, factor $\mathrm{H}$-related protein 1 and fibronectin (Dallo et al., 2002; Kunert et al., 2007).

Affinity chromatography appproach to identify the interactions between pathogen proteins and proteinaceous targets in the host, based on the use of immobilized host's ligand as an affinity selector, is a good starting point for preparing a list of cell wall-associated proteins that bind this ligand (Boleij et al., 2011). However, it requires that the whole extract from the cell wall should contain the proteins in native conformations, with the original binding activites preserved. In our study, we released the fungal cell wall-associated proteins using $\beta$-1,3-glucanse that digests $\beta$-1,3-glucan network that the proteins are covalently anchored to or embedded in (Casanova et al., 1992; Crowe et al., 2003). The applied procedure minimized possible contaminations of the cell wall extract with accidentally released cytoplasmic proteins. Nevertheless, because the entire method can generate some misidentification, e.g., due to an insufficient specificity of the affinity gel, secondary proteinprotein interactions, etc., we qualified the identified contact factor-binders as "putative" and felt that their actual binding affnities to HK, FXII or PPK should be more directly confirmed. It should be stressed that the most direct approach - isolation of pathogen proteins in native conformations and physicochemical tests for binding to host's targets - has been only occasionally applied in the research on the interactions between fungal cell wall proteins and human proteins, mainly due to some inherent technical difficulties.

In this study, we successfully isolated and purified the active forms of five candidal proteins — Als3, Tpi1, Pgi1, Eno1 and Gpm1 — and used an advanced physicochemical method of SPR measurements to characterize, for the first time, the kinetics and thermodynamics of their interactions with HK, FXII and PPK. Only a few similar studies, with extracellular matrix proteins as targets, have been reported so far (Donohue et al., 2011; Jordan et al., 2014; Ielasi et al., 2014).

As presented in Table 2, the thermodynamic dissociation constants for the complexes of contact factors with chip-immobilized fungal proteins varied within a relatively narrow range, between $7.21 \times 10^{-8} \mathrm{M}$ (for the Tpi1FXII complex) and $7.33 \times 10^{-7} \mathrm{M}$ (for the Eno1-FXII complex). On a very broad scale of the dissociation constants for biologically relevant protein-protein complexes (Tudos \& Schasfoort, 2008), these interactions should by classified as of a moderate strength. Previous, simple estimations of a "technical" $K_{0.5}$ parameter for the saturable binding of $\mathrm{HK}, \mathrm{FXII}$ and PPK to $C$. albicans germ tubes gave the values of $2.7 \times 10^{-7} \mathrm{M}, 3.6 \times 10^{-8} \mathrm{M}$ 
and $1 \times 10^{-8} \mathrm{M}$, respectively (Rapala-Kozik et al., 2008; Karkowska-Kuleta et al., 2010). For the interaction of the mixture of candidal cell wall proteins with plasminogen, a $K_{0.5}$ value of $1.12 \times 10^{-7} \mathrm{M}$ was reported (Crowe et al., 2003).

Although the Als3 protein was classified as a putative PPK binder, the interactions between these two proteins could not be confirmed with SPR measurements. The reasons for this discrepancy between two methods are not clear. At the moment, one can assume that the immobilization of Als3 on the CM5 chips involves the molecule fragment that is essential for the interaction with PPK. In the affinity chromatographic experiment, entire surface of Als3 molecule can interact with PPK, immobilized in agarose via a long hydrophilic spacer. In contrast to PPK, both $\mathrm{HK}$ and FXII tightly bound to Als3, with the dissociation constants of $1.74 \times 10^{-7} \mathrm{M}$ and $2.13 \times 10^{-7} \mathrm{M}$, respectively. In the SPR study of the interactions between the N-terminal fragment of Als1 and extracellular matrix proteins, fibronectin and laminin, the values, higher by $1-2$ orders of magnitude, i.e., $1.6 \times 10^{-6}$ $\mathrm{M}$ and $1.3 \times 10^{-5} \mathrm{M}$, were measured, respectively (Donohue et al., 2011). For binding of fibronectin to N-terminal fragment of epithelial adhesin 1 of C. glabrata, a value of $9.11 \times 10^{-7} \mathrm{M}$ was determined by the SPR method (Ielasi et al., 2014). These comaprisons suggest that the interactions of candidal adhesins with extracellular matrix proteins - a biologically relevant function of all fungal adhesins - are significantly weaker than the binding of FXII and HK. This confirms the high stickiness of these two components of the contact system, and probably reflects a different biological significance of the fungal adhesion to host tissues and the immune evasion through sequestering or activating regulatory proteins of the host.

Among other contact factor-binding proteins studied here, that all belong to the group of moonlighting proteins, Tpi1 was exceptional in terms of the highest affinity $\left(<10^{-8} \mathrm{M}\right)$ to HK and FXII, and Pgil was distinguished by exclusive binding of PPK. For this group of fungal proteins, almost no reference data could be found in the literature, except an estimation of the dissociation constant of $6.0 \times 10^{-8} \mathrm{M}$ for the interaction of the kringle domain 1-3 of human plasminogen to Listeria monocytogenes enolase (Schaumburg et al., 2004).

In kinetic terms, the binding of contact factors to candidal cell wall-associated proteins is reasonably fast, with the association rate constants within a range of $1.57 \times 10^{4}$ to $3.86 \times 10^{5} \mathrm{M}^{-1} \mathrm{~s}^{-1}$. The rate constants within the same order of magnitude were reported for many biologically relevant protein-protein interactions (Tudos \& Schasfoort, 2008). It is mainly the highest rate for the association of Tpi1 with HK and FXII that accounts for the high affinity of this particular fungal protein to contact factors.

In conclusion, in the present study we unequivocally identified the interactions of several candidal cell wallassociated proteins with human factors involved in the contact-activated release of important proinflammatory mediators. The complexes formed were kinetically and thermodynamically characterized, using the surface plasmon resonance spectroscopy. The identified fungal-host interactions are potential targets for novel anticandidal therapeutic approaches.

\section{Acknowledgements}

This work was supported in part by the Ministry of Science and Higher Education, Poland (grant no. N N303 572538 awarded to A.K.), and the Nation- al Science Centre of Poland (grant no. 2012/07/B/ NZ1/02867 awarded to A.K.). Some MS measurements were performed using a MicroTOF spectrometer that was purchased by the European Regional Development Fund as part of the Polish Innovation Economy Operational Program (contract no. POIG.02.01.00-12-167/08, project Małopolska Center of Biotechnology). The Faculty of Biochemistry, Biophysics and Biotechnology of the Jagiellonian University in Krakow is a beneficiary of structural funds from the European Union (grant no. POIG.02.01.00-12-064/08, "Molecular biotechnology for health") and a partner of the Leading National Research Center (KNOW) supported by the Ministry of Science and Higher Education, Poland.

The authors declare no conflict of interest.

\section{REFERENCES}

Ballantyne DS, Warmington JR (2000) Purification of native enolase from medically important Candida species. Biotechnol Appl Biochem 31: 213-218. http://dx.doi.org/10.1042/BA19990106.

Barbasz A, Kozik A (2009) The assembly and activation of kinin-forming systems on the surface of human U-937 macrophage-like cells. Biol Chem 390: 269-275. http://dx.doi.org/10.1515/BC.2009.032.

Ben Nasr AB, Herwald H, Müller-Esterl W, Björck L (1995) Human kininogens interact with $M$ protein, a bacterial surface protein and virulence determinant. Biochem J 305: 173-180.

Blais C Jr, Marceau F, Rouleau JL, Adam A (2000) The kallikrein-kininogen-kinin system: lessons from the quantification of endogenous kinins. Peptides 21: 1903-1940.

Boleij A, Laarakkers CM, Gloerich J, Swinkels DW, Tjalsma H (2011) Surface-affinity profiling to identify host-pathogen interactions. Infect Immun 79: 4777-4783. http://dx.doi.org/10.1128/IAI.05572-11.

Bradford MM (1976) A rapid and sensitive method for the quantitation of microgram quantities of protein utilizing the principle of protein-dye binding. Anal Biochem 72: 248-254. http://dx.doi. org/10.1016/0003-2697(76)90527-3.

Casanova M, Lopez-Ribot JP, Martinez JP, Sentandreu R (1992) Characterization of cell wall proteins from yeast and micelial cells of Candida albicans by labelling with biotin: comparison with other techniques. Infect Immun 60: 4898-4906.

Chaffin WL (2008) Candida albicans cell wall proteins. Microbiol Mol Biol Rev 72: 495-544. http://dx.doi.org/10.1128/MMBR.00032-07.

Colman RW, Schmaier AH (1997) Contact system: a vascular biology modulator with anticoagulant, profibrinolytic, antiadhesive, and proinflammatory attributes. Blood 90: 3819-3843.

Costa-Neto CM, Dillenburg-Pilla P, Heinrich TA, Parreiras-E-Silva LT, Pereira MG, Reis RI, Souza PP (2008) Participation of kallikreinkinin system in different pathologies. Int Immunopharmacol 8: 135142. http://dx.doi.org/10.1016/j.intimp.2007.08.003.

Crowe JD, Sievwright IK, Auld GC, Moore NR, Gow NA, Booth NA (2003) Candida albicans binds human plasminogen: identification of eight plasminogen-binding proteins. Mol Microbiol 47: 1637-1651.

Dallo SF, Kannan TR, Blaylock MW, Baseman JB (2002) Elongation factor $\mathrm{Tu}$ and $\mathrm{E} 1 \mathrm{\beta}$ subunit of pyruvate dehydrogenase complex act as fibronectin binding proteins in Mycoplasma pneumoniae. Mol Microbiol 46: 1041-1051. http://dx.doi.org/10.1046/j.13652958.2002.03207.x.

De Groot PWJ, Bader O, de Boer AD, Weig M, Chauhan N (2013) Adhesins in human fungal pathogens: glue with plenty of stick. Eukaryot Cell 12: 470-481. http://dx.doi.org/10.1128/EC.00364-12.

Donohue DS, Ielasi FS, Goossens KVY, Willaert RG (2011) The Nterminal part of Als1 protein from Candida albicans specifically binds fucose-containing glycans. Mol Microbiol 80: 1667-1679. http:// dx.doi.org/10.1111/j.1365-2958.2011.07676.x.

Filler SG (2006) Candida-host cell receptor-ligand interactions. Curr Opin Microbiol 9: 333-339. http://dx.doi.org/10.1016/j.mib.2006.06.005.

Filler SG, Sheppard DC, Edwards JE Jr (2006) Molecular basis of fungal adherence to endothelial and epithelial cells. In Molecular principles of fungal pathogenesis. Heitman J, Filler SG, Edwards JE Jr, Mitchell AP eds, pp 187-196. ASM Press. http://dx.doi.org /10.3201/ eid1210.060832.

Free SJ (2013) Fungal cell wall organization and biosynthesis. Adv Genet 81: 33-82. http://dx.doi.org/10.1016/B978-0-12-407677-8.00002-6.

Frick IM, Björck L, Herwald H (2007) The dual role of the contact system in bacterial infectious disease. Thromb Haemost 98: 497-502. http://dx.doi.org/10.1160/TH07-01-0051.

Furuya H, Ikeda R (2009) Interaction of triosephosphate isomerase from the cell surface of Staphylococcus aureus and alpha-(1->3)mannooligosaccharides derived from glucuronoxylomannan of 
Cryptococcus neoformans. Microbiology 155: 2707-2713. http://dx.doi. org/10.1099/mic.0.028068-0.

Heilmann CJ, Sorgo AG, Klis FM (2012) News from the fungal front: wall proteome dynamics and host-pathogen interplay. PLoS Pathog 8: e1003050. http://dx.doi.org/10.1371/journal.ppat.1003050.

Henderson L, Figueroa CD, Muller-Esterl W, Bhoola KD (1994) Assembly of contact-phase factors on the surface of the human neutrophil membrane. Blood 84: 474-482.

Herwald H, Mörgelin M, Olsén A, Rhen M, Dahlbäck B, Müller-Esterl W, Björck L (1998) Activation of the contact-phase system on bacterial surfaces - a clue to serious complications in infectious diseases. Nat Med 4: 298-302. http://dx.doi.org/10.1038/nm0398-298.

Ielasi FS, Verhaeghe T, Desmet T, Willaert RG (2014) Engineering the carbohydrate-binding site of Epa1p from Candida glabrata: generation of adhesin mutants.

with different carbohydrate specificity. Glycobiology 24: 1312-1322. http://dx.doi.org/10.1093/glycob/cwu075.

Jong AY, Chen SH, Stins MF, Kim KS, Tuan TL, Huang SH (2003) Binding of Candida albicans enolase to plasmin(ogen) results in enhanced invasion of human brain microvascular endothelial cells. $J$ Med Microbiol 52: 615-622. http://dx.doi.org/10.1099/jmm.0.050600 .

Jordan RPC, Williams DW, Moran GP, Coleman DC, Sullivan DJ (2014) Comparative adherence of Candida albicans and Candida dubliniensis to human buccal epithelial cells and extracellular matrix proteins. Med Mycol 52: 254-263. http://dx.doi.org/10.1093/mmy/ myt032.

Joseph K, Ghebrehiwet B, Kaplan AP (2001) Activation of the kininforming cascade on the surface of endothelial cells. Biol Chem 382 $71-75$.

Kainulainen V, Loimaranta V, Pekkala A, Edelman S, Antikainen J, Kylväjä R, Laaksonen M, Laakkonen L, Finne J, Korhonen TK (2012) Glutamine synthetase and glucose-6-phosphate isomerase are adhesive moonlighting proteins of Lactobacillus crispatus released by epithelial cathelicidin LL-37. J Bacteriol 194: 2509-2519. http:// dx.doi.org/10.1128/JB.06704-11.

Karin M, Lawrence T, Nizet V (2006) Innate immunity gone awry: linking microbial infections to chronic inflammation and cancer. Cell 124: 823-835. http://dx.doi.org/10.1016/j.cell.2006.02.016.

Karkowska-Kuleta J, Kedracka-Krok S, Rapala-Kozik M, Kamysz W, Bielinska S, Karafova A, Kozik A (2011) Molecular determinants of the interaction between human high molecular weight kininogen and Candida albicans cell wall: Identification of kininogen-binding proteins on fungal cell wall and mapping the cell wall-binding regions on kininogen molecule. Peptides 32: 2488-2496. http://dx.doi. org/10.1016/j.peptides.2011.10.021

Karkowska-Kuleta J, Kozik A (2014) Moonlighting proteins as virulence factors of pathogenic fungi, parasitic protozoa and multicellular parasites. Mol Oral Microbiol 29: 270-283. http://dx.doi. org/10.1111/omi.12078.

Karkowska-Kuleta J, Kozik A, Rapala-Kozik M (2010) Binding and activation of the human plasma kinin-forming system on the cell walls of Candida albicans and Candida tropicalis. Biol Chem 391: 98-103. http://dx.doi.org/10.1515/BC.2009.145.

Karkowska-Kuleta J, Rapala-Kozik M, Kozik A (2009) Fungi pathogenic to humans: molecular bases of virulence of Candida albicans, Cryptococcus neoformans, and Aspergillus fumigatus. Acta Biochim Pol 56: 211-224.

Klis FM, Sosinska GJ, de Groot PW, Brul S (2009) Covalently linked cell wall proteins of Candida albicans and their role in fitness and virulence. FEMS Yeast Res 9: 1013-1028. http://dx.doi.org/10.1111/ j.1567-1364.2009.00541.x.

Kunert A, Losse J, Gruszin C, Huhn M, Kaendler K, Mikkat S, Volke D, Hoffmann R, Jokiranta TS, Seeberger H, Moellmenn U, Hellwage J, Zipfel PF (2007) Immune evasion of the human pathogen Pseudomonas aeruginosa: elongation factor Tuf is a factor $\mathrm{H}$ and plasminogen binding protein. J Immunol 179: 2979-2988. http://dx.doi. org/10.4049/jimmunol.179.5.2979.

Laemmli UK (1970) Cleavage of structural proteins during the assembly of the head of bacteriophage T4. Nature 227: 680-685. http:// dx.doi.org/10.1038/227680a0.

Lin J, Oh S-H, Jones R, Garnett JA, Salgado PS, Rusnakova S, Matthews SJ, Hoyer LL, Cota E (2014) The peptide-binding cavity is essential for Als3-mediated adhesion of Candida albicans to human cells. J Biol Chem 289: 18401-18412. http://dx.doi.org/10.1074/jbc. M114.547877.
López-Villar E, Monteoliva L, Larsen MR, Sachon E, Shabaz M, Pardo M, Pla J, Gil C, Roepstorff P, Nombela C (2006) Genetic and proteomic evidences support the localization of yeast enolase in the cell surface. Proteomics 6 (Suppl 1): S107-S118. http://dx.doi. org/10.1002/pmic.200500479.

Luo S, Poltermann S, Kunert A, Rupp S, Zipfel PF (2009) Immune evasion of the human pathogenic yeast Candida albicans: Pra1 is a Factor H, FHL-1 and plasminogen binding surface protein. Mol Immunol 47: 541-550. http://dx.doi.org/10.1016/j. molimm.2009.07.017.

Mavor AL, Thewes S, Hube B (2005) Systemic fungal infections caused by Candida species: epidemiology, infection process and virulence attributes. Curr Drug Targets 6: 863-874. http://dx.doi. org/10.2174/138945005774912735.

Oehmcke S, Herwald H (2010) Contact system activation in severe infectious diseases. J Mol Med (Berl) 88: 121-126. http://dx.doi. org/10.1007/s00109-009-0564-y.

Pancholi V (2001) Multifunctional alpha-enolase: its role in diseases. Cell Mol Life Sci 58: 902-920.

Pfaller MA, Diekema DJ (2007) Epidemiology of invasive candidiasis: A persistent public health problem. Clin Microbiol Rev 20: 133-163. http://dx.doi.org/10.1128/CMR.00029-06.

Phan QT, Myers CL, Fu Y, Sheppard DC, Yeaman MR, Welch WH, Ibrahim AS, Edwards JE Jr, Filler SG (2007) Als3 is a Candida albicans invasin that binds to cadherins and induces endocytosis by host cells. PLoS Biol 5: e64. http://dx.doi.org/10.1371/journal. pbio.0050064.

Pitarch A, Abian J, Carrascal M, Sánchez M, Nombela C, Gil C (2004) Proteomics-based identification of novel Candida albicans antigens for diagnosis of systemic candidiasis in patients with underlying hematological malignancies. Proteomics 4: 3084-3106. http://dx.doi. org/10.1002/pmic.200400903.

Pitarch A, Díez-Orejas R, Molero G, Pardo M, Sánchez M, Gil C, Nombela C (2001) Analysis of the serologic response to systemic Candida albicans infection in a murine model. Proteomics 1: 550-559. http://dx.doi.org/10.1002/1615-9861(200104)1:4<550::AID_ PROT550>3.0.CO;2-W.

Pitarch A, Sánchez M, Nombela C, Gil C (2002) Sequential fractionation and two-dimensional gel analysis unravels the complexity of the dimorphic fungus Candida albicans cell wall proteome. Mol Cell Proteomics 1: 967-982.

Poltermann S, Kunert A, von der Heide M, Eck R, Hartmann A, Zipfel PF (2007) Gpm1p is a factor H-, FHL-1-, and plasminogenbinding surface protein of Candida albicans. J Biol Chem 282: $37537-$ 37544. http://dx.doi.org/10.1074/jbc.M707280200.

Rapala-Kozik M, Bras G, Chruscicka B, Karkowska-Kuleta J, Sroka A, Herwald H, Nguyen KA, Eick S, Potempa J, Kozik A (2011) Adsorption of components of the plasma kinin-forming system on the surface of Porphyromonas gingivalis involves gingipains as the major docking platforms. Infect Immun 79: 797-805. http://dx.doi. org/10.1128/IAI.00966-10.

Rapala-Kozik M, Karkowska J, Jacher A, Golda A, Barbasz A, Guevara-Lora I, Kozik A (2008) Kininogen adsorption to the cell surface of Candida spp. Int Immunopharmacol 8: 237-241. http://dx.doi. org/10.1016/j.intimp.2007.07.005.

Schaumburg J, Diekmann O, Hagendorff P, Bergmann S, Rohde M, Hammerschmidt S, Kärst U (2004) The cell wall subproteome of Listeria monocytogenes. Proteomics 4: 2991-3006. http://dx.doi. org/10.1002/pmic.200400928.

Sheppard DC, Yeaman MR, Welch WH, Phan QT, Fu Y, Ibrahim AS, Edwards JE (2004) Functional and structural diversity in the Als protein family of Candida albicans. J Biol Chem 279: 30480-30489. http://dx.doi.org/10.1074/jbc.M401929200.

Sundstrom P, Aliaga GR (1992) Molecular cloning of cDNA and analysis of protein secondary structure of Candida albicans enolase, an abundant, immunodominant glycolytic enzyme. J Bacteriol 174: 6789-6799.

Tronchin G, Pihet M, Lopes-Bezerra LM, Bouchara JP (2008) Adherence mechanisms in human pathogenic fungi. Med Mycol 46: 749472. http://dx.doi.org/10.1080/13693780802206435.

Tudos AJ, Schasfoort RBM (2008) Introduction to Surface Plasmon Resonance. In Handbook of Surface Plasmon Resonance. Schasfoort RBM, Tudos AJ eds, pp 1-14. RSC Publishing. http://dx.doi. org/10.1039/9781847558220. 